\title{
Conducting the Needs Assessment \#2: Using Needs Assessments in Extension Programming ${ }^{1}$
}

Matthew Benge and Laura Warner ${ }^{2}$

\section{Introduction to Using Needs}

Assessments in Extension

\section{Programming}

This is the second publication in the Conducting the Needs Assessment series. It provides Extension educators and other service providers a foundational underpinning of how the needs assessment fits within the program planning process. Both formal and nonformal educators seeking to develop and deliver an educational program must first be informed of what their audience lacks in order to develop the right curriculum or training (Etling \& Maloney, 1995); therefore, conducting a needs assessment is a priority in the program development process.

\section{The Extension Program Development Process}

Cooperative Extension's mission is to help local communities solve problems by translating research into educational programs and learning activities for farmers, ranchers, communities, youth, and families throughout the nation (USDA NIFA, 2019). Extension agents carry out this mission and are responsible for meeting the needs within their local communities (Rasmussen, 1989). Extension professionals must first understand what their communities' needs are before they begin planning educational programs for their local clientele. Though each state's
Extension system is different, they follow a similar program development process, which benefits from sound needs assessments when planning Extension programs.

The program development model is made up of three primary processes: (1) program planning; (2) program design and implementation; and (3) program evaluation (see Figure 1). When linked together with thoughtful and intentional planning, these components provide the foundation for successful Extension programming.

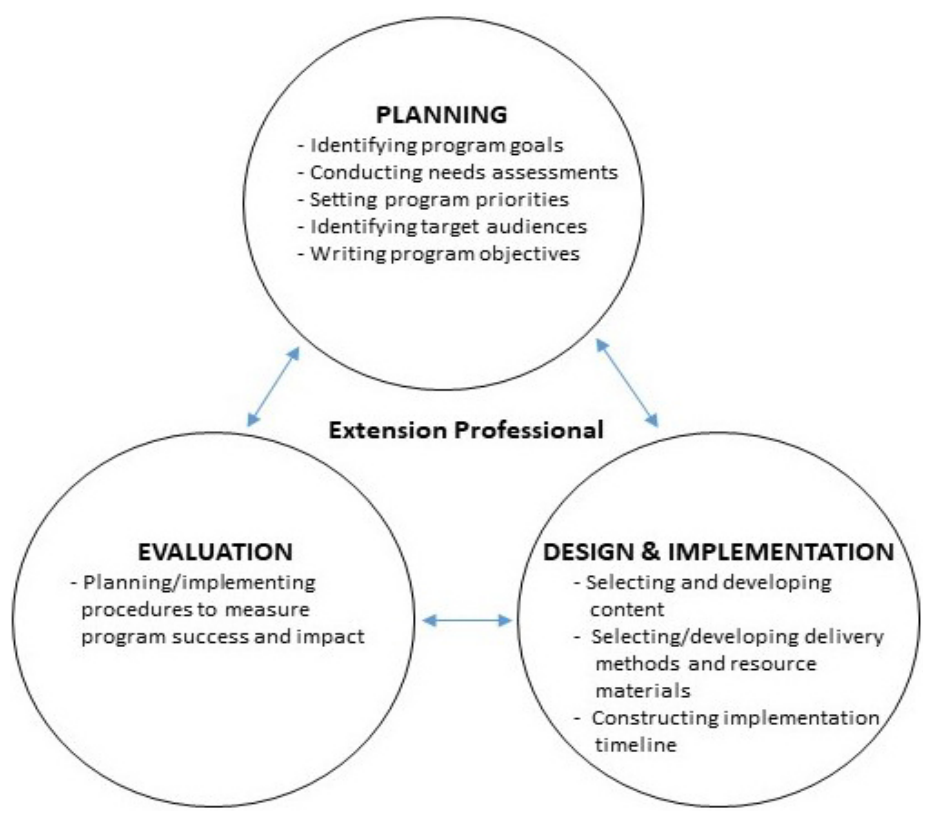

Figure 1. The program development model. Credits: Adapted from Seevers, Graham, Gamon, \& Conklin, 1997

1. This document is AEC684, one of a series of the Department of Agricultural Education and Communication, UF/IFAS Extension. Original publication date December 2019. Visit the EDIS website at https://edis.ifas.ufl.edu for the currently supported version of this publication.

2. Matthew Benge, assistant professor, and Laura Warner, associate professor, Department of Agricultural Education and Communication, UF/IFAS Extension, Gainesville, FL 32611.

The Institute of Food and Agricultural Sciences (IFAS) is an Equal Opportunity Institution authorized to provide research, educational information and other services

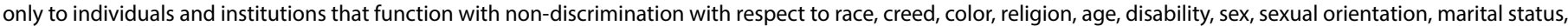

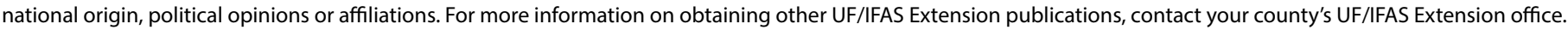
U.S. Department of Agriculture, UF/IFAS Extension Service, University of Florida, IFAS, Florida A \& M University Cooperative Extension Program, and Boards of County Commissioners Cooperating. Nick T. Place, dean for UF/IFAS Extension. 
Program Planning. Planning is the first step in the program development process, creating a "map for the program that addresses who, what, when, where, why, and with what resources" (Seevers et al., 1997, p. 92). Extension professionals should begin with the end in mind (Diem, 2003) by setting program goals and conducting a needs assessment (if one has not been done already). Educators cannot deliver the appropriate program and achieve the desired broader outcomes without first understanding what is needed.

Program Design and Implementation. As the second step, program design and implementation builds upon program planning by converting identified needs into objectives, selecting and creating a curriculum to meet these objectives, identifying appropriate resource materials and modes of delivery, creating an evaluation plan, and implementing the educational program (Boone, Safrit, \& Jones, 2002). This step is what most people envision when thinking of the program development process.

Program Evaluation. Evaluation is critical to the entire program development process and often the step most overlooked (Seevers et al., 1997). Newcomer, Hatry, and Wholey (2015) explain that the "demand for systematic data on the performance of public and nonpublic programs continues to rise" (p. 7) and is becoming increasingly important as Extension is being held more accountable for the funds it is given (Baughman, Boyd, \& Kelsey, 2012).

\section{Importance of a Needs Assessment}

Beyond the traditional understanding of community needs, many reasons point to the importance of understanding those needs. Etling and Maloney (1995) highlight eight unique reasons why the needs assessment is important.

A Key Part of the Program Planning Process. Understanding the expressed and unfelt needs of your clientele and community is integral to planning educational programs targeted to match your program goals. An "educator must exhibit considerable objectivity in working with publics" and they "sometimes tend to assume they know what is best" for their clientele (Boone et al., 2002, p. 148).

A Principle of Democracy. "People should be involved in decisions that affect them. They should help plan programs where they are expected to be participants" (Etling \& Maloney, 1995, p. 10). Targeted clientele should have a voice in what is being taught or instructed rather than receiving information without input. Potential participants are more willing to engage in an educational program if they have a hand in the program planning process.

Motivation. Program participants are motivated to learn best when they know the educational program fulfills a need or desire they have. Knowles (1984), who is considered the father of adult learning, explained service receivers (clientele receiving the program or benefits) should be involved in the planning process to ensure the information presented is valuable and worthy of their time. Potential participants will likely be more motivated to engage in the program if they believe it can help them in their lives (Knowles, Holton, \& Swanson, 2005).

Accountability. Transparency of programmatic efforts, outcomes, and impacts is being more and more demanded by stakeholders, policy makers, and government officials (Ladewig, 1999). Demonstrating a relevant need can help communicate to these opinion leaders that the programmatic efforts you are doing, or that you want to do, are important to their own communities.

Support. "Program support depends on how well we meet documented needs in the community. We need support from members, parents, leaders, decision-makers, donors, other organizations in the community, and others" (Etling \& Maloney, 1995, p. 10), and we may not achieve that support without having the ability to intentionally address identified needs.

Anticipation of Conflicts. Whether you know it or not, various stakeholders within a community may have different ideas as to what services or programs are needed. Listening to one stakeholder alone will not provide you the best outline of what the community is lacking, but the needs assessment process provides a mechanism for gathering input from knowledgeable stakeholders and prioritizing needs when many are identified.

Changing Needs. Simply put, needs change over time. Extension professionals are trained to meet a community's needs at that moment; however, as time progresses, so do a community's needs. Conducting and periodically replicating needs assessments ensures your educational programs are current and relevant for the targeted audience.

A Complex Society. "As societies become more complex, people tend to depend more on others to meet their needs" (Etling \& Maloney, 1995, p. 10). It is unrealistic to meet every need within a community. In some communities, many organizations may provide similar services. A needs assessment can help Extension professionals determine 
both the current needs within a community as well as what other service providers are offering, which ensures your programs are not going to duplicate someone else's work, and may reveal opportunities to partner with other organizations to increase your reach and impact collectively.

\section{Use needs assessment results to guide your Extension program}

Though conducting the needs assessment is an integral component in the program development process, many Extension professionals do not follow through with all of the three phases of a needs assessment. Practitioners commonly "jump in" to the assessment phase without first defining the purpose of considering multiple needs assessment approaches. On the other hand, you may have started your job with access to a completed needs assessment, and perhaps you are thinking, "What do I do with this information"! Conducting the Needs Assessment \#7: Phase 3-Post-assessment provides "the next step" after the needs assessment is conducted.

\section{Conclusion}

This second publication in the Conducting the Needs Assessment series focused on understanding the Extension program planning process and the importance in using needs assessments in Extension programming. For a brief overview of each publication in the series, see Appendix A.

\section{References}

Baughman, S., Boyd, H. H., \& Kelsey, K. D. (2012). The impacts of the government performance and results act (GRPA) on two state Cooperative Extension systems. Journal of Extension, 50(1). Retrieved from https://www.joe. org/joe/2012february/pdf/JOE_v50_1a3.pdf

Boone, E. J., Safrit, R. D., \& Jones, J. (2002). Developing programs in adult education: A conceptual programming model. (2nd ed.). Prospect Heights, IL: Waveland Press, Inc.

Diem, K. G. (2003). Program development in a political world - It's all about impact! Journal of Extension, 41(1). Retrieved from https://www.joe.org/joe/2003february/ a6.php

Etling, A., \& Maloney, T. (1995). Needs assessment for Extension agents and other nonformal educators. Retrieved from https://files.eric.ed.gov/fulltext/ED388774.pdf
Knowles, M. (1984). The adult learner: A neglected species. (3rd ed.). Houston, TX: Gulf Publishing.

Knowles, M. S., Holton; E. F., III; \& Swanson, R. A. (2005). The adult learner. (6th ed.). San Diego, CA: Elsevier.

Ladewig, H. (1999). Acccountability and the Cooperative Extension system [Paper presentation]. Cooperative Extension Program Leadership Conference, Pittsburgh, PA.

Newcomer, K. E., Hatry, H. P., \& Wholey, J. S. (2015). Handbook of practical program evaluation. (4th ed.). Hoboken, NJ: John Wiley \& Son, Inc.

Rasmussen, W. D. (1989). Taking the university to the people: Seventy-five years of Cooperative Extension. Ames, Iowa: Iowa State University Press.

Seevers, B., Graham, D., Gamon, J., \& Conklin, N. (1997). Education through Cooperative Extension. Albany, NY: Delmar Publications.

United States Department of Agriculture/National Institute for Food and Agriculture. (2019). Extension. Retrieved from https://nifa.usda.gov/extension

Witkin, B. R., \& Altschuld, J. W. (1995). Planning and conducting needs assessments: A practical guide. Thousand Oaks, CA: Sage Publications.

\section{Appendix A: Conducting the Needs Assessment Series Overview}

Conducting the Needs Assessment \#1: Introduction

General summary of needs assessments, including what a needs assessment is, the different phases, and tools to conduct a needs assessment.

\section{Conducting the Needs Assessment \#2: Using Needs Assess- ments in Extension Programming}

Overview of using needs assessments as part of the Extension program planning process.

\section{Conducting the Needs Assessment \#3: Motivations, Barri- ers and Objections}

Information about the motivations, barriers, and objections to conducting needs assessments for Extension professionals and service providers. 
Conducting the Needs Assessment \#4: Audience Motivations, Barriers, and Objections

Information about the motivations, barriers, and objections that clientele and communities may have for participating or buying-in to a needs assessment.

Conducting the Needs Assessment \#5: Phase

1-Pre-assessment

Introduction to the Pre-assessment phase of conducting a needs assessment, including defining the purpose, management, identifying existing information, and determining the appropriate methods.

\section{Conducting the Needs Assessment \#6: Phase}

2-Assessment

Introduction to the Assessment phase of conducting a needs assessment, including gathering and analyzing all data.

Conducting the Needs Assessment \#7: Phase

3-Post-assessment

Introduction to the Post-assessment phase of conducting a needs assessment, including setting priorities, considering solutions, communicating results, and evaluating the needs assessment.

\section{Conducting the Needs Assessment \#8: The Borich Model}

Overview of using the Borich Model to conduct a needs assessment.

Conducting the Needs Assessment \#9: The Nominal Group Technique

Overview of using the Nominal Group Technique to conduct a needs assessment.

Conducting the Needs Assessment \#10: The Delphi Technique

Overview of using the Delphi Technique to conduct a needs assessment.

Conducting the Needs Assessment \#11: The Causal Analysis Technique

Overview of using the Causal Analysis Technique to conduct a needs assessment. 